\title{
НАУКОВО-ПРАКТИЧНЕ ОБГРУНТУВАННЯ ВИКОРИСТАННЯ ОРГАНІЧНИХ ОЛІЙ ДЛЯ ПОКРАЩЕННЯ ЖИРНОКИСЛОТНОГО СКЛАДУ ПЕЧИВА
}

\author{
А. С. ТКАЧЕНКО, кандидат технічних наук, доцент \\ (Вищий навчальний заклад Укоопспілки «Полтавський університет економіки і торгівлі»)
}

\begin{abstract}
Анотація. У статті досліджено вплив конопляної та рижієвої олії органічної на жирнокислотний склад печива. Об'єктом дослідження обрані розроблені зразки «Жанет» $i$ «лорі». Встановлено, шзо вміст насичених жирних кислот у розроблених зразках суттєво змениився. У печиві «Флорі» - на 39\%, у печиві «Жанет»-на 45\%. Вміст малоненасичених жирних кислот, навпаки, збільиився. У печиві «Жанет» - на 23\%, а у печиві «Флорі» - на 67\%. Суттєво зріс уміст поліненасичених жирних кислот, які вважаються найціннінішими для здоров'я людини. Якісний склад і кількісний вміст жсирнх кислот у досліджуваних зразках визначали методом газорідинної хроматографії на приладi Agilent 6890 (Agilent Technologies, США). Подальші дослідження планується присвятити вивченню процесу окиснення ліпідів печива під час зберігання.
\end{abstract}

Ключові слова: органічне печиво, жирнокислотний склад, поліненасичені жирні кислоти, насичені жирні кислоти, ліпіди.

Постановка проблеми у загальному вигляді. Борошняні вироби є досить популярним продуктом серед населення [1]. У 2020 р. ринок кондитерської продукції приблизно на 90-91\% забезпечувався внутрішнім виробництвом. Імпорт кондитерської продукції в Україну за результатами 2020 р. становив приблизно 60 тис. т, що займає 9-10\% усього обсягу українського виробництва кондитерської продукції. Маркетингові дослідження свідчать про те, що на ринку печива України функціонують до 5 великих компаній, які утримують ринок, реалізуючи продукцію як на внутрішній ринок, так і на експорт, близько 10 підприємств, які є у більшості регіонів, а також понад 120 підприємств, діяльність котрих зазвичай обмежена регіоном, у якому розташовані потужності. Значна кількість виробників печива зосереджена у міні-пекарнях і кондитерських [2]. Водночас ці вироби характеризуються зазвичай низькою харчовою цінністю та високою калорійністю, що негативно впливає на дітей та осіб похилого віку, оскільки в какао-продуктах міститься речовина теобромін, яка безпосередньо впливає на нервову та серцево-судинну системи [3]. Використання жирів у нутрітивній підтримці зосереджується як на забезпеченні калорійної густини (9 ккал/г) ізотонічного джерела енергії, так і на забезпеченні вмісту незамінної лінолевої кислоти [4]. Перспективним напрямком є збагачення виробів рослинними жирами для покращення жирнокислотного складу.

Аналіз останніх досліджень і публікацій. Збагаченням жирнокислотного складу борошняних виробів присвячені роботи I.В. Сирохмана, В.Т. Лебединець, Т.М. Лозової [5; 6]. Відома технологія виробництва печива з використанням $12 \%$ пасти 3 гігротермічно оброблених кісток риби телапії та насіння льону від маси пшеничного борошна [7]. Це дозволило збагатити печиво омега-3 жирними кислотами, білковими та мінеральними речовинами, зокрема кальцієм, фосфором і ферумом. Встановлено, що за рахунок включення до рецептури нетрадиційних видів олій відбувається збільшення частки ненасичених і зменшення частки насичених жирних кислот у печиві. Покращення жирнокислотного складу печива досягнуто за рахунок внесення до його складу обліпихової, соєвої, лляної олій [8]. Науково підтверджена доцільність використання ріпаку для збагачення білкового та жирнокислотного складу борошняних кондитерських виробів. Ріпакова макуха містить 1,27\% валіну, 0,74\% ізолейцину, 2,44\% лейцину, 1,12\% лізину, 1,46\% треоніну, 2,72\% фенілаланіну та тирозину [9].

Формування цілей статті. Метою роботи $€$ науково-практичне обгрунтування використання органічної рижієвої та конопляної олії для покращення жирнокислотного складу печива. Завдання статті:

1. дослідити можливість застосування органічних олій для рецептури печива;

2. проаналізувати вміст жирних кислот у печиві;

3. визначити склад ненасичених жирних кислот у печиві.

Об'скт і предмет дослідження. Об'єктом дослідження є контрольний зразок печива цукрового за стандартною рецептурою та розроблене печиво органічне. Зведені рецептури нового печива наведені у таблиці 1. 
Таблиця 1

Зведені рецептури

розробленого печива органічного

\begin{tabular}{|l|c|c|}
\hline \multicolumn{1}{|c|}{ Органічна сировина } & «Флорі» & «Жанет» \\
\hline Борошно зі спельти & 420,00 & - \\
\hline Борошно кукурудзяне & - & 380,00 \\
\hline Борошно кокосове & - & 60 \\
\hline Яйця & 21,1 & 23,1 \\
\hline Органічний цукор & 150,00 & - \\
\hline Кокосовий цукор & - & 150,00 \\
\hline Сіль & 0,10 & 0,10 \\
\hline Сода & 0,10 & 0,10 \\
\hline Масло & 105,00 & 105,00 \\
\hline Сухе молоко кокосове & 25,00 & 22,00 \\
\hline Конопляна олія & - & 11,00 \\
\hline Рижісва олія & 12,00 & - \\
\hline Порошок меліси & 7,5 & 6,8 \\
\hline
\end{tabular}

Предметом дослідження $€$ жирнокислотний склад нового печива.

Результати дослідження. Попередніми дослідження автора [10] встановлено, що за рахунок використання нетрадиційних видів олій (лляної, гарбузової, соєвої та каротинової) у виробництві нового печива вдалося знизити частку насичених жирних кислот порівняно із контролем і наблизити жирнокислотний склад виробів до «ідеального ліпіду».

Встановлено, що у конопляній олії співвідношення ненасичених жирних кислот $\omega-3$ i $\omega-6$ збалансоване для здоров'я людини та відповідає рекомендаціям Всесвітньої організації охорони здоров'я (ВОО3 ООН). Відповідно до них людині необхідно від 1 до 3 г $\omega-3$ і 4 г $\omega-6$ жирних кислот у складі олії [11]. Для виготовлення печива органічного «Флорі» було обрані зразок олії Elitephito (конопляна олія органічна), рис. 1.

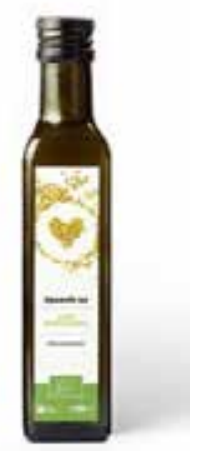

Рис. 1. Конопляна олія органічна

Поживна (харчова) цінність на 100 (г) олії Elitephito (конопляна олія органічна): жири 99,9 г. Енергетична цінність (калорійність) на 100 (г) продукту: 3761 кДж (898,2 Ккал). Продукт органічного виробництва, сертифікований Органік Стандарт UA-BIO-108 відповідно до Стандарту, що еквівалентний Постановам СС № 834/2007, 889/2008. UA-BIO-108.

Рижієва олія характеризується підвищеним вмістом поліненасичених жирних кислот, особливо варто згадати високий вміст $\alpha$-ліноленової кислоти $(24,8 \%)$ і співвідношення $\omega-6 / \omega-3$ як $2: 1$, що дає можливість використовувати цю олії для отримання харчових продуктів збалансованого жирнокислотного складу та збагачення харчового раціону населення незамінними жирними кислотами. Ї̈ можна використовувати і для дієтичного харчування людей, котрі мають підвищений рівень холестерину в крові. Також у значній кількості у ній містяться ненасичені лінолева $(31,5 \%)$, олеїнова $(19,8 \%)$ та ейкозенова $(9,9 \%)$ кислоти. Високий вміст (цис-11, ейкозанової) кислоти $є$ відмінною ознакою рижієвої олії [12]. Для виробництва печива «Жанет» використано олію рижієву органічну нерафіновану Organico, рис. 2.

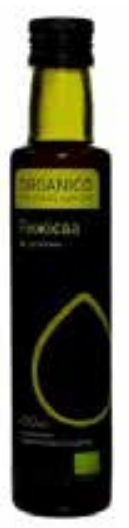

Рис. 2. Рижієва олія органічна

Поживна (харчова) цінність на 100 (г) олії становить: жири, г/100г - 99, енергетична цінність: ккал/100г - 896; кДж/100г - 3760.

Дослідження жирнокислотного складу рижієвої та конопляної органічних олій наведено у попередніх роботах автора [13]. Результати свідчать про збалансований жирнокислотний склад рослинних олій. Було встановлено, що їх внесення у рецептуру виробів може вплинути на біологічну цінність ліпідної основи печива, збагативши ii есенціальними жирними кислотами. Жирнокислотний склад печива визначали методом газової хроматографії на газовому хроматографі НР 6890 (Agilent, США), (рис. 3). Використовували колонку капілярну НP-5ms $(30 \mathrm{~m} \times 0,25 \mathrm{мм} \times 0,25$ мкм, Agilent Technologies, США). Температура випарника $-250^{\circ} \mathrm{C}$, температура інтерфейсу $-280^{\circ} \mathrm{C}$. Поділ проводили у режимі програмування температури - початкову температуру $60^{\circ} \mathrm{C}$ витримували протягом 4 хв, iз градієнтом $4^{\circ} \mathrm{C} / \mathrm{xв}$ піднімали до $250^{\circ} \mathrm{C}$, витримували 6 хв, із градієнтом $20^{\circ} \mathrm{C}$ піднімали до $300^{\circ} \mathrm{C}$, витримували 5 хв $[14 ; 15]$. 
Таблиця 2

Жирнокислотний склад печива органічного

\begin{tabular}{|l|c|c|c|}
\hline \multicolumn{1}{|c|}{ Назва жирної кислоти } & Контроль & «Флорі» & «Жанет» \\
\hline Капринова (С 10:0) & 0,04 & 0,01 & 0,01 \\
\hline Лаурінова (С 12:0) & 0,03 & 0,15 & 0,03 \\
\hline Міристинова (С 14:0) & 0,48 & 0,13 & 0,18 \\
\hline Пентадеканова (С 15:0) & 0,11 & 0,00 & 0,00 \\
\hline Пальмітинова (С 16:0) & 2,55 & 2,11 & 2,00 \\
\hline Маргаринова (С 17:0) & 0,14 & 0,01 & 0,01 \\
\hline Стеаринова (С 18:0) & 1,56 & 0,61 & 0,56 \\
\hline Арахінова (С 20:0) & 0,12 & 0,06 & 0,00 \\
\hline Разом насичені жирні кислоти: & 5,03 & 3,08 & 2,79 \\
\hline Пальмітолеїнова (С 16:1) & 0,03 & 0,07 & 0,09 \\
\hline Олеїнова (С 18:1) & 2,50 & 2,89 & 3,99 \\
\hline Ерукова (С 22:1) & 0,00 & 0,06 & 0,08 \\
\hline Гондова (С20:1) & 0,00 & 0,08 & 0,09 \\
\hline Нервонова(С 24:1) & 0,00 & 0,02 & 0,02 \\
\hline Разом МНЖК & 2,53 & 3,12 & 4,27 \\
\hline Лінолева (С 18:2) & 1,34 & 2,80 & 3,87 \\
\hline Ліноленова (С 18:3) & 0,06 & 1,90 & 2,90 \\
\hline Арахідонова (С 20:4) & 0,01 & 0,06 & 0,09 \\
\hline Разом ПНЖК & 2,83 & 8,5 & 10,11 \\
\hline
\end{tabular}

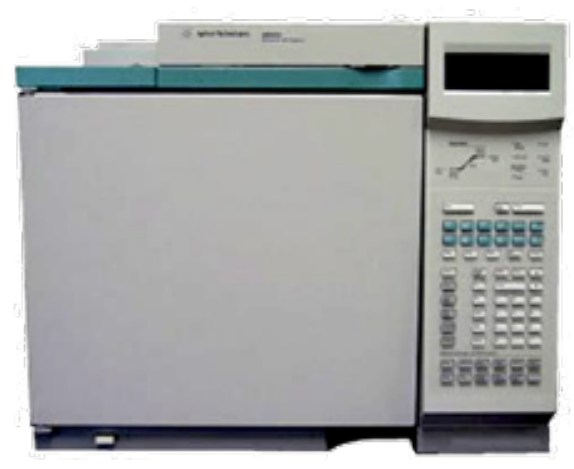

Рис. 3. Газовий хроматограф НР 6890 (Agilent, CIIA)

Жирнокислотний склад розроблених зразків наведено у таблиці 2.

Як свідчать дані таблиці 2, вміст насичених жирних кислот у розроблених зразках суттєво зменшився. У печиві «Флорі» - на $39 \%$, у печиві «Жанет» - на 45\%. Вміст малоненасичених жирних кислот, навпаки, збільшився. У печиві «Жанет» - на 23\%, у печиві «Флорі» - на 67\%. Суттєво зріс уміст поліненасичених жирних кислот, які вважаються найціннінішими для здоров'я людини. Варто зазначити, що вміст лінолевої кислоти зріс у зразку «Флорі» у 2 рази, а у зразку
«Жанет»-у 2,88 раза. Вміст ліноленової кислоти зріс у 31 і 48 разів відповідно. У дослідженнях [13] було встановлено, що конопляна олія краща за жирнокислотним складом, ніж рижієва. Це підтверджується дослідженнями жирнокислотного складу печива, адже зразок «Жанет», до складу якого увійшла конопляна олія, переважає за вмістом моно- і полі- ненасичених жирних кислот.

Висновки. Внесення органічних олій конопляної та рижієвої позитивно впливає на жирнокислотний склад печива. Доведено, що заначені олії мають високий вміст поліненасичених жирних кислот. Вміст насичених жирних кислот у розроблених зразках суттєво зменшився. У печиві «Флорі» - на 39\%, у печиві «Жанет»на 45\%. Вміст малоненасичених жирних кислот, навпаки, збільшився. У печиві «Жанет» - на $23 \%$, а у печиві «Флорі» - на $67 \%$. У новому печиві збільшився уміст поліненасичених жирних кислот, які вважаються найціннінішими для здоров'я людини. Варто зазначити, що вміст лінолевої кислоти зріс у зразку «Флорі» у 2 рази, а у зразку «Жанет» - у 2,88 раза. Вміст ліноленової кислоти зріс у 31 і 48 разів відповідно. Подальші дослідження планується присвятити вивченню процесу окиснення ліпідів печива під час зберігання.

\section{СПИСОК ВИКОРИСТАНИХ ДЖЕРЕЛ}

1. Єрмак С.О., Плотницька В.В. Інноваційні аспекти розвитку ринку кондитерських виробів України. Бізнес Інформ. 2016. № 11. С. 398-403.

2. Разумова Г.В., Оскома О.В. Кондитерський ринок України: аналіз та перспективи розвитку. Theoretical and methodological approaches to the formation of a modern system of national and international enterprises, organizations and institutions'development. 2021. C. 2-10. 
3. Мотузка Ю.М. Жирнокислотний склад продуктів для ентерального харчування. Технологї̈ харчової та легкої промисловості. 2017. № 3 (9). С. 155-162.

4. Cairns P.A., Stalker D.T. Carnitine supplementation of parenterally fed neonates. Cochrane Database Syst. Rev. 2000: CD000950.

5. Сирохман I.В., Лебединець В.Т. Вплив нетрадиційних добавок на поліпшення жирнокислотного складу вафель. Наукові праці [Одеської національної академї харчових технологій]. 2009. Вип. 36 (1). С. $147-150$.

6. Лозова T.М., Сирохман I.В. Наукові основи формування споживних властивостей і зберігання якості борошняних кондитерських виробів : монографія. Львів : Вид-во Львівської комерційної академії, 2009. 456 с.

7. Aly R. Abdel-Moemin. Healthy cookies from cooked fish bones. Food Bioscience. 2015. Vol. 12. P. 114-121.

8. Tkachenko A., Pakhomova I. Consummer properties improvement of sugar cookies with fillings with nontraditional raw materials with high biological value. Eastern-European Journal of Enterprise Technologies. 2016. Vol 3. № 11 (81). P. 54-61. URL: http://journals.uran.ua/eejet/article/view/70950/66914.

9. Підвищення харчової цінності печива цукрового / Н.В. Новікова, Т.В. Воронова, М.В. Шинкарук та ін. Таврійський науковий вісник. 2020. № 15. С. 191-196.

10. Ткаченко А.С. Формування споживних властивостей печива цукрового підвищеної харчової цінності : автореф. дис. ... канд. техн. наук : 85 05.18.15 / Укоопспілка, Львівська комерційна академія. Львів, 2015.25 с. URL: http://www.irbis-nbuv.gov.ua (дата звернення: 24.04.2018).

11. Конопляна сировина: нові перспективи для харчової промисловості / Н.В. Роль, В.М Надточій, А.Д. Цебро та ін. Технологія виробниитвва і переробки продукиії тваринництвва. 2021. № 1. С. 151-158.

12. Очеретна А.В., Орлова Н.Е. Дослідження якісного складу олії рижію та перспектив їі використання в дієтичному харчуванні. Вчені записки ТНУ імені В.І. Вернадського. Серія: технічні науки. 2020. Т. 31 (70) Ч. 2 . № 6. C. $76-81$.

13. Research of quality and safety indicators of organic raw materials for development of new cookie recipes / A Tkachenko, I Syrokhman, L Guba at.al. EUREKA: Life Sciences. 2020. № 3. P. 36-40.

14. Investigation of phenolic compounds of Antennaria dioica (L.) Gaertn. Herb / S. Marchyshyn, R. Basaraba, T. Berdey. The Pharma Innovation Journal. 2017. № 6 (8). P. 09-11.

15. Бурлака І.С., Кисличенко В.С. Дослідження ліпофільних фракцій трави куничника звичайного та щучника дернистого. Укр. мед. альм. 2011. 14, № 2. С. 38-39.

\section{REFERENCES}

1. Yermak, S. \& Plotnitska,V. (2016). Innovatsiyni aspekty rozvytku rynku kondyters'kykh vyrobiv. Biznes Inform, 11, 398-403 [in Ukrainian].

2. Razumova, G. \& Oskoma, O. (2021). Kondyters'kyy rynok Ukrayiny: analiz ta perspektyvy rozvytku. Theoretical and methodological approaches to the formation of a modern system of national and international enterprises, organizations and institutions' development, 2-10.

3. Motuzka, Yu. (2017) Zhyrnokyslotnyy sklad produktiv dlya enteral'noho kharchuvannya. Tekhnolohiyi kharchovoyi ta lehkoyi promyslovosti, 155-162.

4. Cairns, P.A. \& Stalker D.T. (2000). Carnitine supplementation of parenterally fed neonates. Cochrane Database Syst. Rev.

5. Syrokhman, I. \& Lebedynets, V. (2009). Vplyv netradytsiynykh dobavok na polipshennya zhyrnokyslotnoho skladu vafel. Naukovi pratsi [Odes'koyi natsional'noyi akademiyi kharchovykh tekhnolohiy], 36 (1), $147-150$.

6. Lozova, T. \& Syrokhman, I. (2009). Naukovi osnovy formuvannya spozhyvnykh vlastyvostey i zberihannya yakosti boroshnyanykh kondyters'kykh vyrobiv : monohrafiya, 456.

7. Aly, R. Abdel-Moemin. (2015). Healthy cookies from cooked fish bones. Food Bioscience, Volume 12, $114-121$.

8. Tkachenko, A. \& Pakhomova, I. (2016). Consummer properties improvement of sugar cookies with fillings with non-traditional raw materials with high biological value. Eastern-European Journal of Enterprise Technologies, Vol 3, № 11 (81), p. 54-61

9. Novikova, N., Voronova, T., Shynkaruk, M. (2020). Pidvyshchennya kharchovoyi tsinnosti pechyva tsukrovoho. Tavriys'kyy naukovyy visnyk, 15, 191-196.

10. Tkachenko, A. (2015). Formuvannya spozhyvnykh vlastyvostey pechyva tsukrovoho pidvyshchenoyi kharchovoyi tsinnosti avtoref. dys. ... kand. tekhn. nauk : 8505.18 .15

11. Rol', V., Nadtochy, A. Cebro [at.al]. (2021). Konoplyana syrovyna: novi perspektyvy dlya kharchovoyi promyslovosti, Tekhnolohiya vyrobnytstva i pererobky produktsiyi tvarynnytstva, 1, 151-158.

12. Ocheretna, A.\& Orlova, N. (2020). Doslidzhennya yakisnoho skladu oliyi ryzhiyu ta perspektyv yiyi vykorystannya v diyetychnomu kharchuvanni. Vcheni zapysky TNU imeni V.I. Vernads'koho. Seriya: tekhnichni nauky, 31 (70), 6, 76-81.

13. Tkachenko, A. \& Syrokhman, I., Guba, L. [at.al]. (2020). Research of quality and safety indicators of organic raw materials for development of new cookie recipes / A Tkachenko. EUREKA: Life Sciences, 3, 36-40.

14. Marchyshyn, S., Basaraba, R., Berdey, T. (2017). Investigation of phenolic compounds of Antennaria dioica (L.) Gaertn. Herb The Pharma Innovation Journal, No. 6 (8), 09-11.

15. Burlaka, I. \& Kyslyhenko, V. (2011). Doslidzhennya lipofil'nykh fraktsiy travy kunychnyka zvychaynoho ta shchuchnyka dernystoho, 14, 2, 38-39. 
A. Tkachenko, PhD, Associated Professor (Poltava University of Economics and Trade). Scientific and practical rationale for the use of organic oils to improve the fatty acid composition of cookies.

Abstract. The article investigates the effect of hemp and rye oil on the fatty acid composition of cookies. The ratio of unsaturated fatty acids $\omega-3$ and $\omega-6$ in hemp oil has been found to be balanced for human health and in accordance with the recommendations of the World Health Organization. Rye oil is characterized by a high content of polyunsaturated fatty acids. The developed samples "Janet" and "Flory" were selected as the object of research. A sample "Elitephito oil" (organic hemp oil) was chosen to make "Flori" organic cookies. Unrefined Organic rye oil is used for the production of "Jane"t cookies. It contains a significant amount of unsaturated linoleic (31.5\%), oleic $(19.8 \%)$ and eicosenic $(9.9 \%)$ acids. It was found that the content of saturated fatty acids in the developed samples decreased significantly. In the "Flori" cookies - by 39\%, in the "Janet" cookies - by 45\%. The content of low-saturated fatty acids on the contrary increased. In the "Janet" cookies - by $23 \%$, and in the "Flori" cookies by $67 \%$. The content of polyunsaturated fatty acids, which are considered to be the most valuable for human health, has increased significantly. The content of linoleic acid increased in the sample "Flori" 2 times, and in the sample "Janet"-2.88 times. The linolenic acid content increased 31 and 48 times, respectively. The qualitative composition and quantitative content of fatty acids in the test samples were determined by gas-liquid chromatography on an Agilent 6890 instrument (Agilent Technologies, USA). The results of the study are of practical importance for the food industry. Further prospects of the study will be devoted to the study of the oxidation of lipids in cookies during storage.

Key words: organic cookies, fatty acid composition, polyunsaturated fatty acids, saturated fatty acids, lipids. 